\title{
Differential effects of histamine on Leydig cell and testicular macrophage activities in wall lizards: precise role of $\mathrm{H} 1 / \mathrm{H} 2$ receptor subtypes
}

\author{
Uniza W Khan and Umesh Rai \\ Comparative Immunoendocrinology Laboratory, Department of Zoology, University of Delhi, Delhi 110 007, India \\ (Requests for offprints should be addressed to U Rai; Email: rai_u@rediffmail.com)
}

\begin{abstract}
The present study in the wall lizard, Hemidactylus flaviviridis, was aimed to understand the role of histamine (HA) in the regulation of Leydig cell and testicular macrophage activities, for the first time, in ectothermic vertebrates. Although HA did not affect the testosterone production from unstimulated Leydig cells, it had dual concentration-related effects, stimulatory at a low concentration of $10^{-10} \mathrm{M}$ while inhibitory at a high concentration of $10^{-5} \mathrm{M}$, on FSH-induced testosterone production. This suggests that HA did not influence the basal Leydig cell steroidogenesis, but modulated the FSH-stimulated testosterone production in a biphasic manner depending upon its concentration. However, HA failed to affect the FSHstimulated Leydig cell proliferation, indicating that HA modulated the testosterone production from Leydig cells
\end{abstract}

without influencing their proliferation in wall lizards. HA, apart from Leydig cells, differentially regulated the testicular macrophage immune responses. It inhibited phagocytosis and superoxide production at high concentration $\left(10^{-5} \mathrm{M}\right)$, while stimulated superoxide production and could not affect phagocytosis at low concentration $\left(10^{-10} \mathrm{M}\right)$. Using selective $\mathrm{H} 1$ and $\mathrm{H} 2$ antagonists, pyrilamine and famotidine respectively, $\mathrm{H} 1$ receptor subtype was seen responsible for mediating the inhibitory effect of HA on Leydig cell steroidogenesis and testicular macrophage immune responses at high concentration, while $\mathrm{H} 2$ receptors were involved for the stimulation at low concentration.

Journal of Endocrinology (2007) 194, 441-448

\section{Introduction}

Research on paracrine control of Leydig cell activity in mammals has primarily focused upon the factors secreted from Sertoli cells in the seminiferous tubule (Lejeune et al. 1996, Grisswold \& Mclean 2006). In the last decade, there has been a groundswell of interest in understanding the interrelationship between Leydig cells and testicular macrophages (Haider 2004, Hutson 2006). Moreover, lymphocytes and low number of mast cells are also present in the interstitial compartment of the testis (Gaytan et al. 1989, Pinart et al. 2001). Mast cells are shown to be the main source of histamine (HA) in the testis (Albrecht et al. 2005). In addition, germ cells are also reported to add in testicular HA milieu (Safina et al. 2002). In recent years, efforts have been made to investigate the role of HA in control of Leydig cell steroidogenesis, though the reports are limited and the results are contradictory (Mayerhofer et al.1989, Mondillo et al. 2005). Intriguingly, the role of HA in control of testicular macrophage immune responses has not been studied so far, despite the fact that mast cells and macrophages are present in the testicular microenvironment and known for their immunoregulatory functions (Beer et al.1984, Azuma et al. 2001, Fijak \& Meinhardt 2006, Hedger \& Hales 2006).
In wall lizards, testicular macrophages are present in substantial numbers along with Leydig cells in a ratio of 1:3-4 in the interstitial tissue (unpublished observation). The presence of mast cells in testicular interstitial tissue has been demonstrated in the lizard Podarcis s. sicula (Minucci et al. 1995) and other non-mammalian vertebrate (Di Matteo et al. 2000). However, no information is available on the role of HA, principally a mast cell-secreted product, in paracrine regulation of Leydig cell and macrophage activities in ectothermic vertebrates. In the light of these observations, the present study in wall lizards was aimed to provide direct evidence of the role of HA in homeostatic control of Leydig cell steroidogenesis and proliferation, and testicular macrophage immune responses. In addition, attempts were also made to demonstrate the existence of specific functional HA receptors on Leydig cells and testicular macrophages.

\section{Materials and Methods}

\section{Animals}

Adult male wall lizards, Hemidactylus flaviviridis, of 8-10 g body weight were procured locally (Delhi: latitude, 
$28^{\circ} 12^{\prime}-28^{\circ} 53^{\prime} \mathrm{N}$; longitude, $\left.76^{\circ} 50^{\prime}-77^{\circ} 23^{\prime}\right)$ in the months of May to July (regressed phase) and acclimated to laboratory conditions for 1 week prior to the experiment. They were maintained (12 h light: $12 \mathrm{~h}$ darkness) in wooden cages with wire mesh on the sides and top, and fed live insects ad libitum. The guidelines of the Committee for the Purpose of Control and Supervision of Experiments on Animals, Ministry of Statistics and Programme Implementation, Government of India were followed in the maintenance and killing of animals.

\section{Reagents and culture media}

Dulbecco's modified Eagle's medium/Hams F-12 medium (DMEM/F-12, 1:1 mixture), collagenase type 1, bacterial lipopolysaccharide (Escherichia coli Serotype 55:B5), phorbol myristate acetate (PMA), 3-(4,5-dimethylthiazol-2-yl)-2,5diphenyltetrazolium bromide (MTT), nitroblue tetrazolium (NBT), percoll, SDS, HA dihydrochloride, and selective antagonists pyrilamine $(\mathrm{P})$ and famotidine $(\mathrm{F})$ for $\mathrm{HA}$ receptor subtypes $\mathrm{H} 1$ and $\mathrm{H} 2$ respectively were purchased from Sigma chemicals Co. Ovine follicle-stimulating hormone (oFSH16, AFP-5592C) was a kind gift from NIDDK (Torrance, CA, USA). As per the technical details of oFSH, the contamination with other pituitary hormones was negligible. Giemsa stain was obtained from Merck India Ltd and other routine chemicals were purchased from SRL Pvt Ltd (Mumbai, India). Tritiated thymidine (methyl- ${ }^{3} \mathrm{H}-\mathrm{TdR}$; $2 \cdot 0 \mathrm{Ci} / \mathrm{mmol}$ ) was purchased from the Board of Radiation and Isotope Technology (BRIT, Bombay, India).

The culture medium was supplemented with $40 \mu \mathrm{g} / \mathrm{ml}$ gentamycin, $100 \mu \mathrm{g} / \mathrm{ml}$ streptomycin, $100 \mathrm{IU} / \mathrm{ml}$ penicillin (Ranbaxy India Ltd, New Delhi, India), $50 \mu \mathrm{M}$ $\beta$-mercaptoethanol, and $25 \mathrm{mM}$ HEPES buffer (Merck India Ltd), and the $\mathrm{pH}$ was adjusted to $7 \cdot 2$. The fetal calf serum (FCS; Biological Industries, Kibbutz Beit Haemek, Israel) was heat inactivated and added to the culture medium prior to use.

\section{Isolation of testicular interstitial cells}

Leydig cell-enriched fraction Leydig cells from regressed testes of wall lizards were isolated following the procedure of Khan \& Rai (2005). In brief, the lizards were killed, and the testes were taken out, pooled, and transferred to cold DMEM/F-12 medium containing 2\% FCS. After washing, the testes were decapsulated, chopped, resuspended in cold culture medium, and shaken gently to disperse the tubules. The suspension was kept on ice for 15-20 min at unit gravity to sediment the tubules. The supernatant containing Leydig cells, macrophages, and other interstitial cells were decanted. This process was repeated thrice. The pellet of interstitial cells was obtained following centrifugation at $200 \mathrm{~g}$ for $5 \mathrm{~min}$ at $4{ }^{\circ} \mathrm{C}$ (step 1). In addition, to minimize the loss of Leydig cells, a pellet of seminiferous tubules was treated with collagenase $(0.9 \mathrm{mg} / \mathrm{ml})$, shaken in a water bath for $10-15 \mathrm{~min}$ at $25^{\circ} \mathrm{C}$,
$1 \mathrm{ml} \mathrm{FCS}$ was added, and the suspension was kept on ice to stop the enzymatic reaction. The dispersed tubular suspension was passed through the tea strainer to remove the tubules. After that, the suspension was centrifuged at $200 \mathrm{~g}$ to obtain the Leydig cells (step 2). The pellet of Leydig cells was washed thrice. Finally, the Leydig cell pellets from step 1 and 2 were resuspended in $1 \mathrm{ml}$ culture medium for percoll gradient centrifugation. The maximum number of Leydig cells present in $30-40 \%$ of percoll gradient were separated out by centrifugation at $200 \mathrm{~g}$ for $5 \mathrm{~min}$ at $4{ }^{\circ} \mathrm{C}$. The pellet of Leydig cells was washed and resuspended in culture medium containing 5\% FCS. The density of Leydig cells was adjusted to $1.6 \times 10^{6}$ cells $/ \mathrm{ml}$. They were identified by $\Delta^{5}-3 \beta$ hydroxysteroid dehydrogenase enzyme test. The viability was determined by Trypan blue exclusion. The purity of Leydig cells ranged from 80 to $90 \%$ with $70-75 \%$ viability. Prior to any experiment, Leydig cells were incubated in medium alone for $24 \mathrm{~h}$ at $25^{\circ} \mathrm{C}( \pm 0 \cdot 1)$ with $5 \% \mathrm{CO}_{2}$.

For testosterone assay, $1 \mathrm{ml} /$ well of Leydig cell suspension was added to a 24-well culture plate. After treatments, the testosterone was estimated in the Leydig cell-conditioned medium by radioimmuno assay (RIA) (Abraham 1974). For Leydig cell proliferation following calorimetric MTT assay (Tian \& Song 2006) or $\left[{ }^{3} \mathrm{H}\right] \mathrm{TdR}$ incorporation (Khan et al. 1992) methods, $200 \mu \mathrm{l} /$ well of Leydig cell suspension was added to a 96-well culture plate. In the case of the MTT assay, after the treatments, the Leydig cells were washed and incubated with $200 \mu \mathrm{l}$ MTT working soluble $(1 \mathrm{mg} / \mathrm{ml})$ for $2 \mathrm{~h}$. Thereafter, cells were washed and solubilized with acidic isopropanol $(0.5 \% \mathrm{SDS}, 0.04 \mathrm{M} \mathrm{HCl}$ in $90 \%$ isopropanol) for $1 \mathrm{~h}$. The absorbance was measured at $570 \mathrm{~nm}$. For $\left[{ }^{3} \mathrm{H}\right] \mathrm{TdR}$ incorporation assay, the Leydig cells were pulsed with $1 \mu \mathrm{Ci}$ $\left[{ }^{3} \mathrm{H}\right] \mathrm{TdR} /$ well $5 \mathrm{~h}$ prior to the completion of incubation. After culture, the Leydig cells were harvested by centrifugation, washed with PBS, and lysed with 1\% SDS (100 $\mu \mathrm{l} /$ well). The radioactivity of the lysate was counted in a liquid scintillation counter (Beckman Fullerton, CA, USA) and the proliferation was expressed in terms of c.p.m. $/ 3 \times 10^{5}$ cells.

\section{Macrophage-enriched fraction}

Macrophages were separated out from testicular interstitial cell suspension following the procedure of Mayerhofer $e t$ al. (1992) with minor modification. In brief, $200 \mu l$ interstitial cell suspension $\left(1.6 \times 10^{6}\right.$ cells $\left./ \mathrm{ml}\right)$ was flooded on a prewashed slide or added to a 96 -well culture plate $(200 \mu \mathrm{l} /$ slide or per well). The macrophages were allowed to adhere by incubating at $25^{\circ} \mathrm{C}$ in a $\mathrm{CO}_{2}$ incubator for $1 \mathrm{~h}$. Nonadherent interstitial cells were washed off with PBS. In the adherent cell population, more than $90 \%$ of cells were macrophages $\left(\sim 0 \cdot 4 \times 10^{6}\right.$ cells $\left./ \mathrm{ml}\right)$, as determined by their morphology following phase contrast, light, and electron microscopy and non-specific esterase activity. Prior to the experiment, macrophages were cultured in medium alone for $24 \mathrm{~h}$. After treatments, phagocytic and respiratory burst 
activities were examined to assess the testicular macrophage immune responses.

The phagocytic assay was performed following the method of Mondal \& Rai (1999). Each slide with adhered testicular macrophages was flooded with a $200 \mu$ heat-killed yeast cell suspension $\left(4 \times 10^{7} \mathrm{cell} / \mathrm{ml}\right)$. After $90 \mathrm{~min}$, the monolayer was washed with PBS, fixed in methanol, and stained with Giemsa. Approximately 100 macrophages on each slide were observed for phagocytosis without any predetermined sequence. The percentage of phagocytosis and the phagocytic index were calculated using the formulae described by Campbell et al. (2001): a) percentage of phagocytosis $=$ number of cells showing phagocytosis/100 macrophages, and b) phagocytic index $=$ percentage of phagocytosis $\times$ number of yeast cells engulfed by a single macrophage. Prior to counting, the technical details of the treatment on each slide were covered. Therefore, the experimenter was blind to the technical details of the slides while counting.

For respiratory burst activity, the intracellular superoxide anion in testicular macrophages was determined by the reduction of redox dye (NBT) following the procedure of Sakai et al. (1996). After treatments, testicular macrophage monolayer was incubated with PBS containing $1 \mathrm{mg} / \mathrm{ml}$ NBT and $1 \mu \mathrm{g} / \mathrm{ml}$ PMA for $2 \mathrm{~h}$, washed, and fixed in methanol. The reduced intracellular product, formazon, was dissolved in $20 \mu \mathrm{l}$ of $0 \cdot 1 \%$ triton X-100, $120 \mu \mathrm{l}$ of $2 \mathrm{M} \mathrm{KOH}$, and $140 \mu \mathrm{l}$ dimethyl sulfoxide (DMSO). The absorbance was recorded at $620 \mathrm{~nm}$ by multiscan spectrophotometer.

\section{In vitro experiments}

Effect of HA and HA antagonists on Leydig cell activities To understand the role of HA in control of Leydig cell activities during the inactive and active states, in vitro concentration-related effect of HA was studied on nonstimulated and FSH-stimulated Leydig cells collected from regressed testis. It would be of interest to note that mammalian FSH is shown to regulate both the testicular functions in many squamates including wall lizards (Callard \& Ho 1980, Khan \& Rai 2004, 2005). In addition, cDNA for only FSH-receptor is cloned so far in squamates (Borrelli et al. 2001, Bluhm et al. 2004). Therefore, in the present study, FSH was used to stimulate the Leydig cell steroidogenesis and proliferation.

Forty-two lizards were killed for each non-stimulated and FSH-stimulated experimental group. The Leydig cells were isolated and incubated with different concentrations of HA from $10^{-10}$ to $10^{-5} \mathrm{M}$, in the presence or the absence of $0.5 \mu \mathrm{g} / \mathrm{ml} \mathrm{FSH}$ (FSH-stimulated and non-stimulated groups) for $24 \mathrm{~h}$. To compare the results, Leydig cells were also incubated in the medium alone or with FSH for $24 \mathrm{~h}$. Thereafter, the conditioned media were processed for testosterone assay and the Leydig cells for proliferation assay.

Selective $\mathrm{H} 1$ and $\mathrm{H} 2$ receptor antagonists, $\mathrm{P}$ and $\mathrm{F}$ respectively, were tested for their ability to antagonize the effect of HA on testosterone production by FSH-stimulated Leydig cells. Concentrations of $\mathrm{H} 1$ and $\mathrm{H} 2$ antagonists ten times higher than HA were used, and therefore, two sets of experiments were made depending on low and high concentration of HA $\left(10^{-5}\right.$ and $10^{-10} \mathrm{M}$ ) used therein. Thirty-six lizards were killed to isolate the Leydig cells for each set of experiments. In the presence of FSH $(0.5 \mu \mathrm{g} / \mathrm{ml})$, the Leydig cells were treated as follows: i) $10^{-5} \mathrm{M} \mathrm{HA}+10^{-4} \mathrm{M} \mathrm{P} / \mathrm{F}$ and ii) $10^{-10} \mathrm{M} \mathrm{HA}$ $+10^{-9} \mathrm{M} \mathrm{P} / \mathrm{F}$. As regards their respective controls, the Leydig cells were incubated with FSH alone, FSH $+10^{-5} / 10^{-10} \mathrm{M}$ $\mathrm{HA}$, and FSH $+10^{-4} / 10^{-9} \mathrm{M} \mathrm{P}$ or F. After 24-h treatment, Leydig cell-conditioned media were processed for testosterone assay.

\section{Effect of $H A$ and $H A$ antagonists on testicular macrophage immune responses}

Thirty-six lizards were killed to prepare the testicular macrophage monolayer for each HA or HA-antagonist experiment. The macrophages were incubated with different concentrations of HA $\left(10^{-10}-10^{-5} \mathrm{M}\right)$ for $3 \mathrm{~h}$. The duration of treatment was finalized based on the literature for rats (Azuma et al. 2001) and our pilot experiment in wall lizards. To assess the effect of $\mathrm{H} 1$ and $\mathrm{H} 2$ antagonists, $\mathrm{P}$ and $\mathrm{F}$ respectively, on HA-induced macrophage immune responses, testicular macrophages were incubated with high and low concentrations of HA and HA antagonists as follows: i) $10^{-5} \mathrm{M} \mathrm{HA}+10^{-4} \mathrm{M} \mathrm{P} / \mathrm{F}$, ii) $10^{-10} \mathrm{M} \mathrm{HA}$ $+10^{-9} \mathrm{M} \mathrm{P} / \mathrm{F}$, iii) $10^{-5} \mathrm{M} \mathrm{HA}$, iv) $\left.10^{-10} \mathrm{M} \mathrm{HA}, \mathrm{v}\right)$ $10^{-4} \mathrm{M} \mathrm{P} / \mathrm{F}$, and vi) $10^{-9} \mathrm{M} \mathrm{P} / \mathrm{F}$ for $3 \mathrm{~h}$. After incubation, the macrophage monolayer was washed and processed for phagocytic and superoxide assay.

\section{Statistical analysis}

Each treatment was carried out in triplicates and repeated thrice $(n=3)$ with different animals to get the reproducibility of results. The data of a single independent experiment were analyzed by one-way ANOVA, compared by Newman-Keuls multiple range test, and represented as mean \pm s.E.M. Oneway ANOVA on ranks was especially applied in case of concentration-related effects of HA on testosterone production by FSH-stimulated Leydig cells and superoxide production by testicular macrophages.

\section{Results}

\section{Effect of $H A$ and $H A$ antagonists on Leydig cell activities}

Although HA did not influence the testosterone production from non-stimulated Leydig cells, it had dose-related biphasic effects on FSH-stimulated Leydig cell steroidogenesis (Fig. 1a). The FSH-stimulated testosterone production significantly $(P<0 \cdot 01)$ increased at a concentration of $10^{-10} \mathrm{M}$ HA. The additive effect of HA, however, 

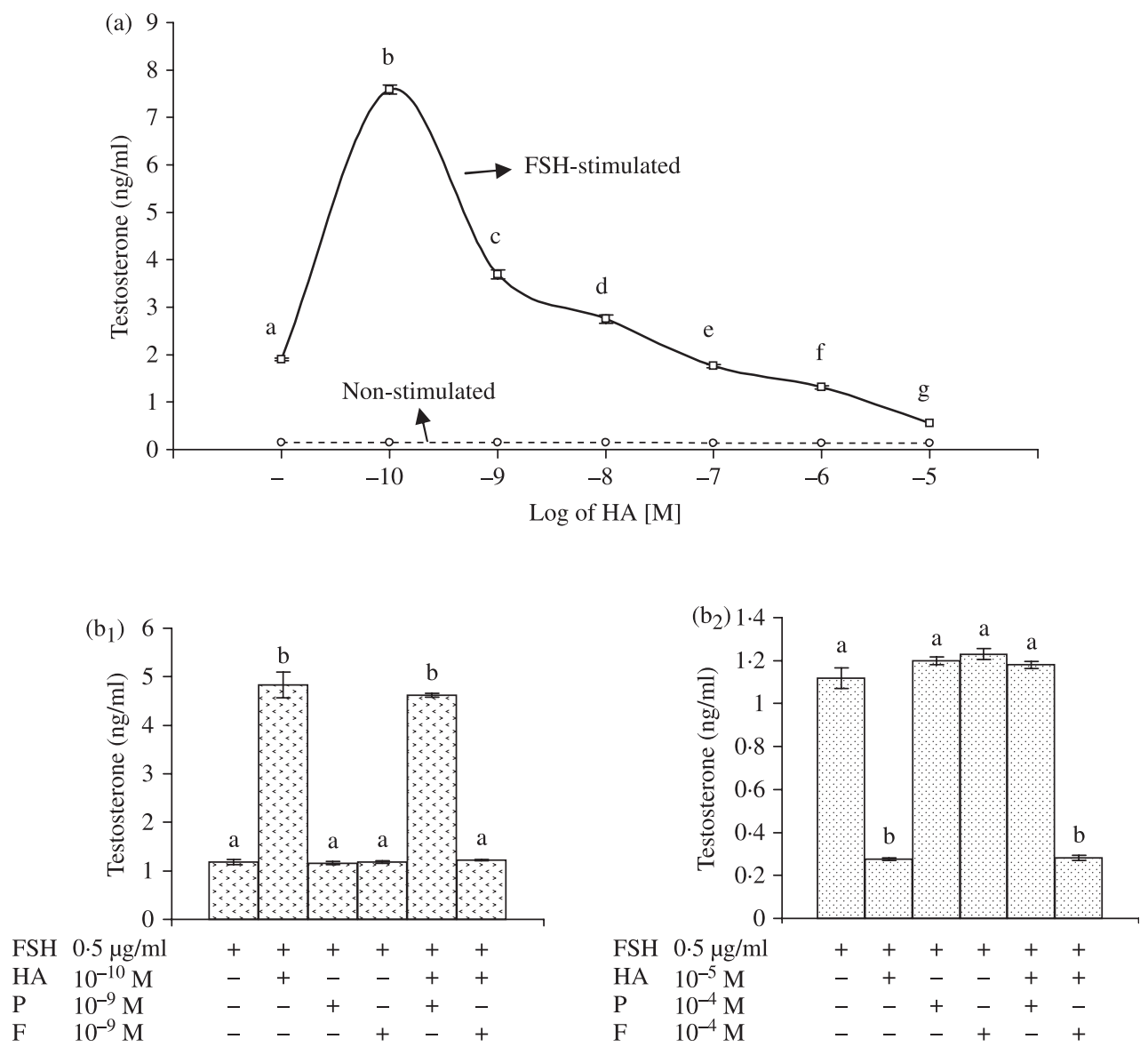

Figure 1 Graph showing the role of histamine $(\mathrm{HA})$ and its specific receptors $(\mathrm{H} 1$ and $\mathrm{H} 2)$ in regulation of Leydig cell steroidogenesis. (a) Non-stimulated and FSH-stimulated Leydig cells were incubated with varying concentrations of $\mathrm{HA}$ ranging from $10^{-10}$ to $10^{-5} \mathrm{M}$. The testosterone was assayed in the condition medium. ( $\mathrm{b}_{1}$ and $\mathrm{b}_{2}$ ) Effect of selective $\mathrm{H} 1$ and $\mathrm{H} 2$ receptor antagonists, pyrilamine $(\mathrm{P})$ and famotidine $(\mathrm{F})$ respectively, on $\mathrm{HA}$-induced differential modulation, stimulation at $10^{-10} \mathrm{M}\left(\mathrm{b}_{1}\right)$, and inhibition at $10^{-5} \mathrm{M}\left(\mathrm{b}_{2}\right)$, of FSH-stimulated testosterone production. Each treatment was carried out in triplicates. Data (mean \pm s.E.M.) represent one of the three independent experiments $(N=3)$. At each time, different lizards were used. Different letters above the error bars indicate that the groups differ significantly at least at $P<0 \cdot 05$.

decreased with the increase of its concentration. Rather, it inhibited the FSH-induced testosterone production at concentrations higher than $10^{-8} \mathrm{M}$ in a dose-dependent manner (Fig. 1a). Further, the additive effect of $10^{-10} \mathrm{M}$ $\mathrm{HA}$ on FSH-stimulated testosterone production was completely antagonized when Leydig cells were incubated with $\mathrm{H} 2$ antagonist, $\mathrm{F}$, while the same was unaffected by the $\mathrm{H} 1$ antagonist, $\mathrm{P}\left(\right.$ Fig. $1 \mathrm{~b}_{1}$ ). On the contrary, the inhibitory effect of $10^{-5} \mathrm{M}$ HA on FSH-stimulated testosterone production by Leydig cells was antagonized by $\mathrm{P}$ only (Fig. $1 b_{2}$ ). Moreover, no detectable change in testosterone level was observed for $\mathrm{P}$ or $\mathrm{F}$ alone at a concentration of $10^{-9} / 10^{-4} \mathrm{M}$ (Fig. $1 \mathrm{~b}_{1}$ and $\mathrm{b}_{2}$ ).

Unlike steroidogenesis, MTT assay (Fig. 2a) or $\left.{ }^{3} \mathrm{H}\right] \mathrm{TdR}$ incorporation (Fig. 2b) exhibited that HA had no effect even on FSH-stimulated Leydig cell proliferation.
Effect of $H A$ and $H A$ antagonists on testicular macrophage immune responses

HA significantly $(P<0 \cdot 01)$ inhibited the phagocytic activities of testicular macrophages at $10^{-7} \mathrm{M}$, while concentrations lower than $10^{-7} \mathrm{M}$ were ineffective as compared with the control. Moreover, a marked $(P<0 \cdot 01)$ increase in HA-induced suppression was observed with the increase of its concentration from $10^{-7}$ to $10^{-6} \mathrm{M}$. However, the inhibition of phagocytic activity at $10^{-5} \mathrm{M}$ was comparable with that observed at $10^{-6} \mathrm{M}$ (Fig. 3a). With regard to involvement of HA receptors, the inhibitory effect of HA $\left(10^{-5} \mathrm{M}\right)$ on the percentage of phagocytosis and the phagocytic index was totally antagonized by $\mathrm{H} 1$ antagonist, P. The $\mathrm{H} 2$ antagonist, $\mathrm{F}$, did not influence the effect of HA on phagocytosis (Fig. 3b). 
(a)

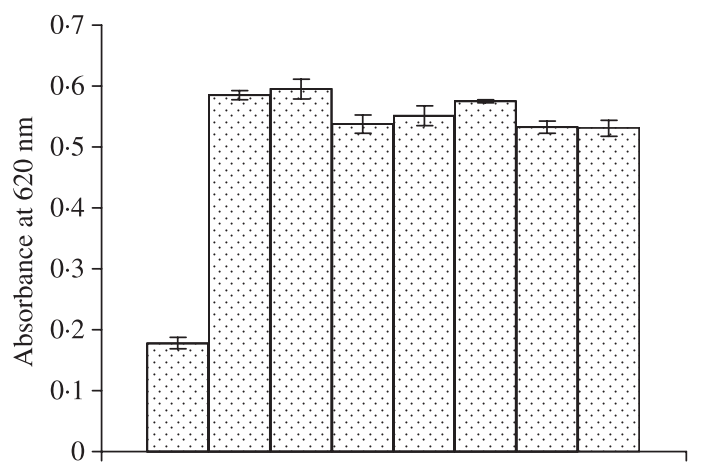

$\begin{array}{lllllllll}\text { Log of HA }[\mathrm{M}] & - & - & -10 & -9 & -8 & -7 & -6 & -5 \\ \text { FSH } 0.5 \mu \mathrm{g} / \mathrm{ml} & - & + & + & + & + & + & + & +\end{array}$

(b)

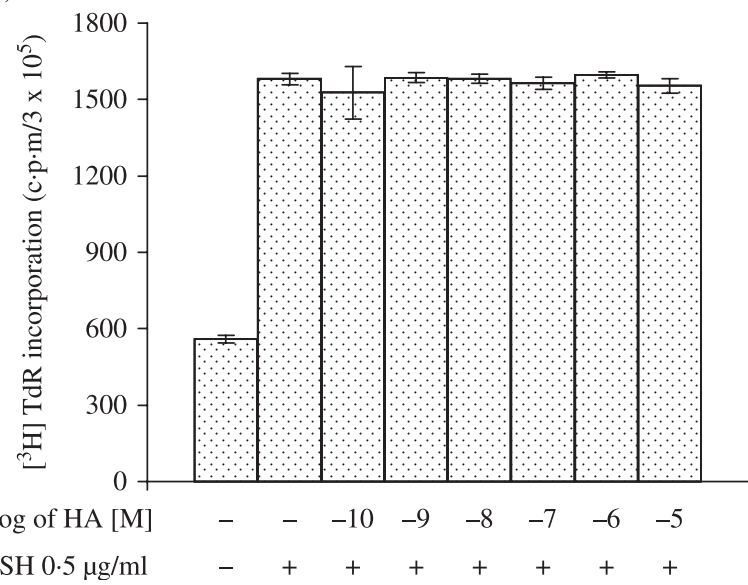

Figure 2 Graph showing no effect of HA on FSH-stimulated Leydig cell proliferation following (a) MTT assay and (b) $\left[{ }^{3} \mathrm{H}\right] \mathrm{TdR}$ incorporation assay. Data expressed as mean \pm s.E.M. are the representative of one of the repeated independent experiments $(n=3)$ using different lizards.

On superoxide production, HA had concentrationdependent biphasic effects, maximally stimulatory at $10^{-10} \mathrm{M}$ and inhibitory at $10^{-5} \mathrm{M}$. The HA-induced stimulation significantly decreased at $10^{-9} \mathrm{M}\left(10^{-10}\right.$ vs $\left.10^{-9} \mathrm{M}, \mathrm{P}<0 \cdot 01\right)$, and culminated in marked inhibition at $10^{-8} \mathrm{M}$ as compared with the control $(P<0 \cdot 05)$. Further, HA-induced inhibition increased with the increase of its concentration from $10^{-8}$ to $10^{-5} \mathrm{M}$ in a dose-dependent manner (Fig. 4a). Both $\mathrm{H} 1$ and $\mathrm{H} 2$ antagonists selectively antagonized the concentration-dependent biphasic effects of $\mathrm{HA}$ on superoxide production (Fig. $4 \mathrm{~b}_{1}$ and $\mathrm{b}_{2}$ ). The $\mathrm{H} 2$ antagonist, F, blocked the stimulatory effect of HA at low $\left(10^{-10} \mathrm{M}\right)$ concentration (Fig. $\left.4 \mathrm{~b}_{1}\right)$, whereas $\mathrm{P}$ nullified the HA-induced inhibition of superoxide production at high $\left(10^{-5} \mathrm{M}\right)$ concentration (Fig. $\left.4 \mathrm{~b}_{2}\right)$. Moreover, $\mathrm{P}$ or $\mathrm{F}$ alone did not have any effect on macrophage immune responses at a concentration of $10^{-9} / 10^{-4} \mathrm{M}$ (Fig. $4 \mathrm{~b}_{1}$ and $\mathrm{b}_{2}$ ). (a)
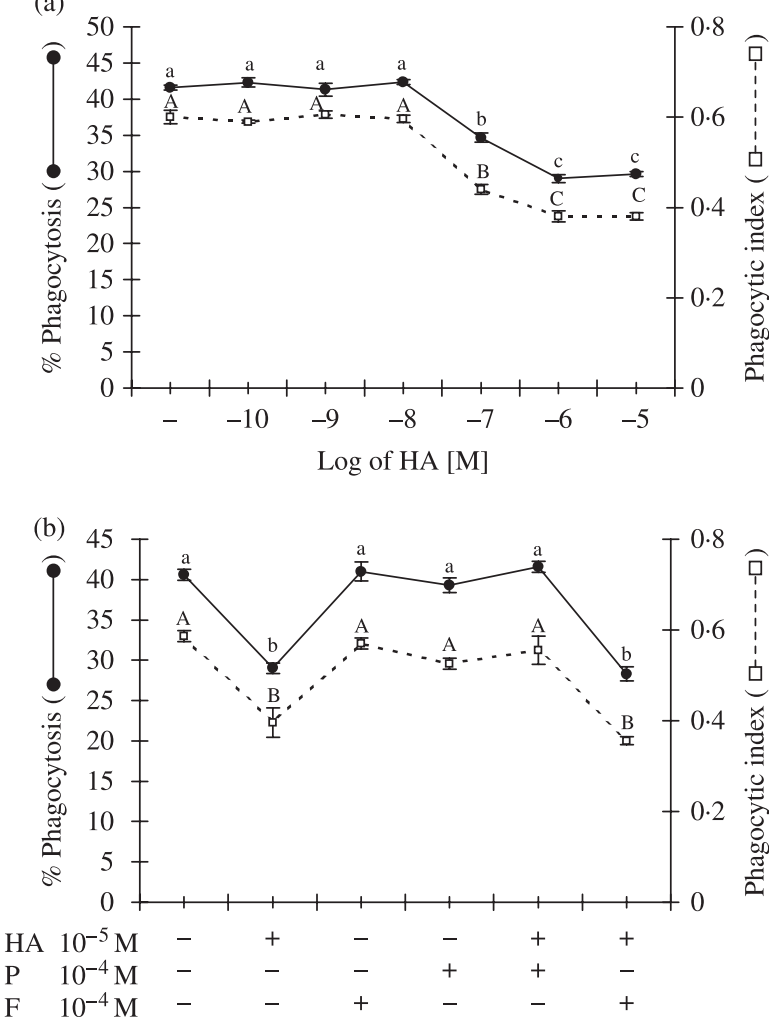

Figure 3 Graph showing the role of histamine $(\mathrm{HA})$ and its specific receptors $\left(\mathrm{H} 1\right.$ and $\left.\mathrm{H}_{2}\right)$ in regulation of testicular macrophage phagocytosis. (a) Concentration-related effect of $\mathrm{HA}$ on the percentage of phagocytosis and the phagocytic index. (b) Effect of $\mathrm{H} 1$ and $\mathrm{H} 2$ receptor antagonists, $\mathrm{P}$ and $\mathrm{F}$ respectively, on $10^{-5} \mathrm{M}$ $\mathrm{HA}$-induced inhibition of the percentage of phagocytosis and the phagocytic index of testicular macrophages. Each treatment was carried out in triplicate, and repeated thrice $(N=3)$ using different animals. Data of one of the representative experiments are shown as mean \pm S.E.M. Values bearing different superscripts differ significantly at $P<0 \cdot 01$.

\section{Discussion}

In the present study, oFSH was used to stimulate the Leydig cell activity since mammalian $\mathrm{FSH}$ is reported to control spermatogenesis as well as steroidogenesis in most of the lizards and snakes (Callard \& Ho 1980, Rai \& Haider 1986, Khan \& Rai 2004, 2005), while luteinizing hormone (LH) was seen either ineffective or less potent in stimulating any of the testicular functions (Licht et al. 1977, Callard \& Ho 1980, Rai \& Haider 1986). In addition, high-affinity binding sites for mammalian FSH are demonstrated in intratubular and interstitial elements of lizard Cnemidophorus testis (Licht \& Midgley 1977). Moreover, only cDNAs encoding FSHreceptor have been described so far in the gonads of lizard (Borrelli et al. 2001) and snake (Bluhm et al. 2004), and attempts to clone cDNA closely related to $\mathrm{LH}$ receptor were unsuccessful (Bluhm et al. 2004). With regard to the existence 

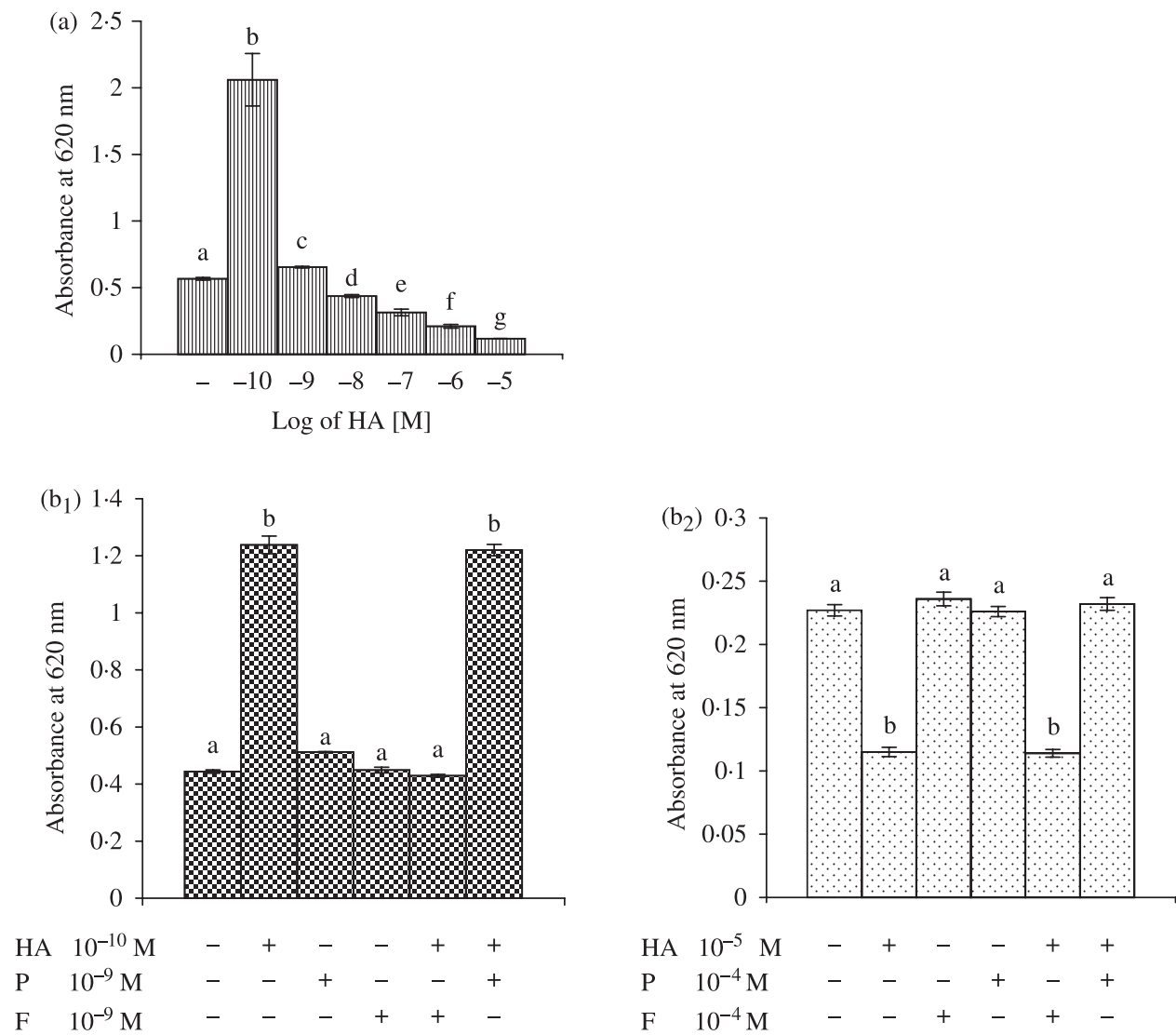

$\begin{array}{llllllll}\mathrm{HA} & 10^{-5} \mathrm{M} & - & + & - & - & + & + \\ \mathrm{P} & 10^{-4} \mathrm{M} & - & - & - & + & - & + \\ \mathrm{F} & 10^{-4} \mathrm{M} & - & - & + & - & + & -\end{array}$

Figure 4 Graph showing the role of $\mathrm{HA}$ and its specific receptors in regulation of superoxide production by testicular macrophage. (a) In vitro concentration-related biphasic effects of HA on superoxide production. Macrophages incubated in medium alone were considered as control. $\left(\mathrm{b}_{1}\right.$ and $\left.\mathrm{b}_{2}\right)$ Effect of $\mathrm{H} 1$ and $\mathrm{H} 2$ receptor antagonists, $\mathrm{P}$ and $\mathrm{F}$ respectively, on $\mathrm{HA}$-induced stimulation at $10^{-10} \mathrm{M}\left(\mathrm{b}_{1}\right)$ and inhibition at $10^{-5} \mathrm{M}\left(\mathrm{b}_{2}\right)$ of superoxide production by testicular macrophages. To compare the results, testicular macrophages were incubated with $10^{-10} / 10^{-5} \mathrm{M} \mathrm{HA}$ or $10^{-9} / 10^{-4} \mathrm{M} \mathrm{P}$ or $\mathrm{F}$ alone. Data of one of the independent experiments that are repeated thrice $(n=3)$ using different animals are expressed as mean \pm S.E.M. Values bearing different superscripts differ significantly at least at $P<0 \cdot 05$.

of pituitary gonadotropins, unlike mammals and many nonmammalian vertebrates, including chelonia and crocodilia of reptiles (Licht 1984, Suzuki et al. 1988, Ando \& Ishi 1994, Saito et al. 2002, Shen \& Yu 2002), biochemical and molecular biology studies identify single gonadotropin in squamates (Licht et al. 1977, 1979, Aizawa \& Ishi 2003). In wall lizards, an in vitro experiment was performed, where oFSH significantly enhanced the steroidogenesis and proliferation of Leydig cells (Khan \& Rai 2005), whereas oLH had no marked effect (unpublished observation). The reported lack of FSH/LH specificity and the presence of single gonadotropin receptor (FSH receptor) may be attributed to single gonadotropin controlling all the testicular functions in most of the squamates (lizards and snakes). This may also be seen in light of reports where porcine FSH receptors recognize turtle LH better than turtle FSH (Moyle et al. 1994), and chicken $\mathrm{LH}$ is shown to bind with rat FSH receptor at an affinity higher than that of chicken FSH (Miya et al. 1994).
The present study showed the differential effects of HA on testosterone production depending upon its concentration and the state of Leydig cells. HA could increase or decrease the testosterone production at low or high concentration respectively, only when Leydig cells were in an activated state in response to FSH. It appears that HA can directly modulate the FSH action on Leydig cells in wall lizards. However, basal levels of Leydig cell steroidogenesis remain unaffected as HA had no effect on testosterone production from non-stimulated Leydig cells. In parallel to our results, the in vitro study using purified rat Leydig cells and murine Leydig cell line (MA-10) demonstrates the concentration-dependent biphasic effects of HA on steroidogenesis, though HA modulated both basal and human chorionic gonadotropin (hCG)-induced steroidogenesis (Mondillo et al. 2005). Contradictory observations are reported in hamster using testicular parenchyma. HA at high concentration is shown to stimulate the testosterone production, while it has no effect at low concentration 
(Mayerhofer et al. 1989). From this study, however, it is not evident that HA directly exerted its effect on the Leydig cells and/or indirectly through other cell types present in the testicular parenchyma. The involvement of other cells/ endocrine organs in modulating the effect of HA on Leydig cell steroidogenesis further came into picture when in vivo (Pap et al. 2002) and in vitro (Mondillo et al. 2006) studies on histidine decarboxylase $(H d c)$ gene knockout mice showed contradictory results. The purified Leydig cells from $\mathrm{Hdc}^{-/-}$ mice secrete low testosterone (Mondillo et al. 2006), while plasma and tissue testosterone levels in $\mathrm{Hdc}^{-/}$mice remain significantly high (Pap et al. 2002) when compared with wildtype mice. Despite controversies, based on the results of the present study and the reports in mammals, it is evident that HA does regulate the testicular steroidogenic function. Interestingly, HA at any concentration did not influence the proliferation of Leydig cells in wall lizards, suggesting that HA effect on Leydig cell steroidogenesis might be due to altered steroidogenic enzymes level rather than increase in Leydig cell number. Moreover, no other report is available regarding the effect of HA on Leydig cell proliferation in any of the vertebrate group.

Like Leydig cells, testicular macrophages of wall lizards responded to HA differentially depending upon its concentration. The phagocytosis and superoxide production decreased at high concentrations of HA. At low concentration, the superoxide production increased, while phagocytosis remained unaffected probably due to the fact that machinery involved in phagocytosis might be less sensitive than that in superoxide production to HA. From these results, it is evident that testicular HA is physiologically important in the local control of testicular macrophage immune responses, and thus maintaining testicular immune balance in wall lizards. Although the physiological role for HA in control of testicular immune balance has not been explored so far, it is shown to inhibit chemotaxis, phagocytosis, and superoxide production by rat peritoneal macrophages in a dosedependent manner (Azuma et al. 2001) and, in contrast, stimulates lung macrophage immune responses in humans (Triggiani et al. 2001). The possible explanation for differential effects of HA on testicular physiology has been put forward in the present study using selective HA antagonists.

The data herein provide evidence that different HArgic receptors were involved in mediating the concentration-related dual effects of HA on Leydig cell steroidogenesis and testicular macrophage immune responses in wall lizards. The inhibition of steroidogenesis at high concentration of HA was selectively antagonized only by $\mathrm{H} 1$ antagonist, pyrilamine, while $\mathrm{H} 2$ receptors were seen to be involved in mediating the stimulatory effect of HA at low concentration, as the effect was reversed only by the $\mathrm{H} 2$ antagonist, F. Similar observations were made by Mondillo et al. (2005) in purified rat Leydig cells and MA-10 Leydig cell line. The occupancy of $\mathrm{H} 2$ receptors is shown to activate the adenylate cyclase system, while the $\mathrm{H} 1$ receptor leads to the generation of inositol triphosphate $\left(\mathrm{IP}_{3}\right)$ (Mondillo et al. 2005), which, in turn, stimulates calcium release from endoplasmic reticulum. With regard to HA receptors in mediating concentration-related biphasic effects of HA on lizard testicular macrophages, the results were comparable with that of Leydig cells. The H1 receptor antagonist counteracted the effect of HA observed at high concentration, while the effect at low concentration was blocked by the $\mathrm{H} 2$ antagonist and not H1. The presence of HA receptors has not been documented on testicular macrophages in any of the vertebrate group. However, at variance to our results, the $\mathrm{H} 2$ receptor has been shown to be responsible for the inhibitory effect of $\mathrm{HA}$ at high concentration on immune responses of macrophages from tissues other than testis (Azuma et al. 2001).

In conclusion, HA differentially regulates the Leydig cell steroidogenesis and testicular macrophage immune responses in wall lizards through selective $\mathrm{HA}$ receptors ( $\mathrm{H} 1$ or $\mathrm{H} 2)$, and thus contributes directly to the homeostatic control of testicular physiology in a paracrine manner.

\section{Acknowledgements}

We are thankful to Dr T G Shrivastava, Department of Reproduction, National Institute of Health and Family Welfare (NIHFW), New Delhi, India, for extending facility and generous help for testosterone RIA. The authors are indebted to the Department of Science and Technology, Government of India, New Delhi for financial assistance. The authors declare that there is no conflict of interest that would prejudice the impartiality of this scientific work

\section{References}

Abraham GE 1974 Radioimmunoassay of steroids in biological fluids. Clinical Biochemistry 7 193-201.

Aizawa Y \& Ishii S 2003 Cloning of complimentary deoxyribonucleic acid encoding follicle-stimulating hormone and luteinizing hormone $B$ subunit precursor molecules in Reeves's turtle (Geoclemys reevesii) and Japanese grass lizard (Takydromus tachydromoides). General and Comparative Endocrinology 132 465-473.

Albrecht M, Frungieri MB, Gonzalez-Calvar S, Meineke V, Kohn FM \& Mayerhofer A 2005 Evidence for a histaminergic system in the human testis. Fertility and Sterility 83 1060-1063.

Ando H \& Ishi S 1994 Molecular cloning of complimentary deoxyribonucleic acids for the glycoprotein hormones alpha-subunit and luteinizing hormone beta-subunit precursor molecules of Japanese quail (Coturnix coturnix japonica). General and Comparative Endocrinology 93 357-368.

Azuma Y, Shinohara M, Wang PL, Hidaka A \& Ohura K 2001 Histamine inhibits chemotaxis, phagocytosis, superoxide anion production, and the production of TNF alpha and IL-12 by macrophages via H2-receptors. International Immunopharmacology 1 1867-1875.

Beer DJ, Matloff SM \& Rocklin RE 1984 The influence of histamine on immune and inflammatory responses. Advance Immunology 36 209-269.

Bluhm APC, Toledo RA, Mesquita FM, Pimenta MT, Fernandes FMC, Ribela MTCP \& Lazari MFM 2004 Molecular cloning, sequence analysis and expression of the snake follicle-stimulating hormone receptor. General and Comparative Endocrinology 137 300-311.

Borrelli L, De Stasio R, Parisi E \& Filosa S 2001 Molecular cloning, sequence and expression of follicle-stimulating hormone receptors in the lizard Podarcis sicula. Gene 2751 149-156. 
Callard IP \& Ho SM 1980 Seasonal reproductive cycle in reptiles. Progress in Reproductive Biology 5-38.

Campbell PA, Canona BO \& Drevets DA 2001 In Measurement of Bacterial Injestion and Killing by Macrophage, vol 3, pp 14.6.1-14.6.13. Eds JE Coligan, AM Kruisbeck, DH Margulies, EM Shevach \& W Strober. New york: Wiley.

Fijak M \& Meinhardt A 2006 The testis in immune privilege. Immunological Reviews 213 66-81.

Gaytan F, Carrera G, Pinilla L, Anguilar R \& Bellido C 1989 Mast cells in the testis, epididymis and accessory glands of the rat: effect of neonatal steroid treatment. Journal of Andrology 3 351-358.

Grisswold MD \& Mclean D 2006 In The Sertoli Cells, 3 , vol 1, pp 949-976. Ed. JD Neill, 3. New York: Academic Press.

Haider SG 2004 Cell biology of Leydig cells in the testis. International Review of Cytology 223 181-241.

Hedger MP \& Hales DB 2006 In Immunophysiology of the Male Reproductive Tract, 3, vol 1, pp 1195-1250. Ed. JD Neill, 3. New York: Acedemic press.

Hutson JC 2006 Physiologic interactions between macrophages and Leydig cells. Experimental Biology and Medicine 231 1-7.

Khan UW \& Rai U 2004 In vitro effect of FSH and testosterone on Sertoli cell nursing function in wall lizard Hemidactylus flaviviridis (Ruppell). General and Comparative Endocrinology 136 225-231.

Khan UW \& Rai U 2005 Endocrine and paracrine control of Leydig cell steroidogenesis and proliferation in the wall lizard: an in vitro study. General and Comparative Endocrinology 140 109-115.

Khan SA, Khan SJ \& Dorrington JH 1992 Interleukin-1 stimulates deoxyribonucleic acid synthesis in immature rat Leydig cells in vitro. Endocrinology 131 1853-1857.

Lejeune H, Chuzal F, Thomas T, Avallet O, Habert R, Durand P \& Saez J 1996 Paracrine regulation of Leydig cells. Annuals of Endocrinology 57 55-63.

Licht P 1984 In Reptiles, vol 1, pp 206-282. Ed. GE Lamming. Edinburgh/London/Melbourne: Churchill Livingstone.

Licht P \& Midgley AR, Jr 1977 Autoradiographic localization of binding sites for human follicle-stimulating hormone in reptilian testes and ovaries. Biology of Reproduction 16 117-121.

Licht P, Papkoff H, Farmer SW, Muller CH, Tsui HW \& Crews D 1977 Evolution in gonadotropin structure and function. Recent Progress in Hormone Research 33 169-248.

Licht P, Farmer SW, Gallo AB \& Papkoff H 1979 Pituitary gonadotropin in snakes. General and Comparative Endocrinology 39 34-52.

Di Matteo I, Izzo-Vitiello I \& Minucci S 2000 Effects of sex steroid hormones and their antagonists on mast cell number in the testis of the frog, Rana esculenta. Zygote 8 225-234.

Mayerhofer A, Bartke A, Amador AG \& Began T 1989 Histamine affects testicular steroid production in the golden hamster. Endocrinology 125 560-562.

Mayerhofer D, Mayerhofer A \& Bartke A 1992 Isolation and culture of testicular macrophages from a seasonally breeding species, Phodopus sungorus. Evidence for functional differences between macrophages from active and regressed testes. International Journal of Andrology 15 263-281.

Minucci S, Izzo-Vitiello I, Marmorino C, Di Matteo C \& Chieffi BG 1995 Mast cell-Leydig cell relationships in the testis of the lizard Podarcis s. sicula Raf: thermal manipulation, ethane 1,2-dimethane sulphonate (EDS) and sex hormone treatment. Zygote 3 259-264.
Miya Y, Wako W \& Ishii S 1994 Rat testicular receptor recognize chicken LH as FSH. Proceedings of the Japan Society for Comparative Endocrinology 957.

Mondal S \& Rai U 1999 Sexual dimorphism in phagocytic activity of wall lizard's splenic macrophages and its control by sex steroids. General and Comparative Endocrinology 116 291-298.

Mondillo C, Patrignani Z, Reche C, Rivera E \& Pignataro O 2005 Dual role of histamine in modulation of Leydig cell steroidogenesis via HRH1 and HRH2 receptor subtypes. Biology of Reproduction 73 899-907.

Mondillo C, Falus A, Pignataaro O \& Pap E 2006 Prolonged histamine deficiency in histidine decarboxylase gene knockout mice affects Leydig cell function. Journal of Andrology 28 86-91.

Moyle WR, Campbell R, Myers RB, Bernard MP, Han Y \& Wang X 1994 Co-evolution of ligand-receptor pairs. Nature 368 251-255.

Pap E, Rácz K, Kovács JK, Vagra I, Buzáa E, Madarász B, Földes A, Szalai C, Ohtsu H, Ichitawa A et al. 2002 Histamine decarboxylase deficiency in gene knockout mice elevates male sex steroid production. Journal of Endocrinology 175 193-199.

Pinart E, Bonet S, Briz M, Sancho S, Garcia N \& Badia E 2001 Cytology of the interstitial tissue in the scrotal and abdominal testes of post-pubertal boars. Tissue and Cell 33 8-24.

Rai U \& Haider S 1986 Effect of mammalian pituitary gonadotropins and testosterone on the testes of sexually quiescent Indian wall lizard, Hemidactylus flaviviridis (Rüppell). Journal of Zoology 210 251-259.

Safina F, Tanaka S, Inagaki M, Tsuboi K, Sugimoto Y \& Ichikawa A 2002 Expression of L-histidine decarboxylase in mouse male germ cells. Journal of Biochemistry 277 14211-14215.

Saito A, Kano Y, Suzuki M, Tomura H, Takeda J \& Tanaka S 2002 Sequence analysis and expression regulation of messenger RNAs encoding B-subunits of follicle-stimulating hormone and Luteinizing hormone in red-billed newt Cynops pyrrhogaster. Biology of Reproduction 66 1299-1309.

Sakai M, Kobayashi M \& Kawauchi H 1996 In vitro activation of fish phagocytic cells by GH, prolactin and somatolactin. Journal of Endocrinology $151113-118$.

Shen ST \& Yu JY 2002 Cloning and gene expression of a cDNA for the chicken follicle-stimulating hormones (FSH)- $\beta$ subunit. General and Comparative Endocrinology 125 375-386.

Suzuki K, Kawauchi H \& Nagahama Y 1988 Isolation and characterization of two distinct gonadotropins form from chum salmon pituitary glands. General and Comparative Endocrinology 71 292-301.

Tian Y \& Song Y 2006 Effects of inositol hexaphosphate on proliferation of HT-29 human colon carcinoma cell line. World Journal of Gastroenterology 12 4137-4142.

Triggiani M, Gentile M, Secondo A, Granata F, Oriente A, Taglialatela M, Annunziato L \& Marone G 2001 Histamine induces exocytosis and IL-6 production from human lung macrophages through interaction with $\mathrm{H} 1$ receptors. Journal of Immunology 166 4083-4091.

Received in final form 7 May 2007

Accepted 10 May 2007

Made available online as an Accepted Preprint

11 May 2007 